Caligrama, Belo Horizonte, v. 23, n. 2, p. 7-40, 2018

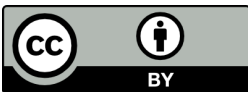

\title{
Particípios passados rizotônicos românicos: um estudo contrastivo entre italiano, espanhol e português
}

\section{Rhizotonic past participles in Romance languages: a contrastive study of Italian, Spanish and Portuguese}

\section{César Nardelli Cambraia}

Universidade Federal de Minas Gerais, Belo Horizonte, Minas Gerais / Brasil nardelli@ufmg.br

\section{Guilherme Henrique Ribeiro Costa}

Universidade Federal de Minas Gerais, Belo Horizonte, Minas Gerais / Brasil silvestrini.2011@gmail.com

Resumo: Este estudo teve como objetivo geral analisar os particípios passados rizotônicos no italiano, no espanhol e no português, a fim de identificar as suas diferenças. Adotou-se como fundamentação teórica a concepção de analogia apresentada por Bynon (1993) e como metodologia a análise de um corpus formado por 247 itens obtidos mediante comparação entre as línguas românicas em questão. Testaram-se duas hipóteses: a primeira era a de que os particípios passados rizotônicos no italiano estariam predominantemente na $2^{\mathrm{a}}$ conjugação, diferentemente do espanhol e do português, o que foi confirmado pelos dados; e a segunda era a de que os particípios passados rizotônicos românicos da $1^{\text {a }}$ conjugação seriam predominantemente inovações românicas, o que também foi confirmado pelos dados. Verificou-se, ainda, que as principais fontes dos particípios passados rizotônicos nas línguas românicas estudadas são: herança de particípios rizotônicos latinos; incorporação de adjetivos latinos; mudanças analógicas e criações analógicas.

Palavras-chave: linguística românica; morfologia; verbo; particípio passado; língua portuguesa; língua espanhola; língua italiana.

Abstract: This study aims to analyze rhizotonic past participles in Italian, Spanish, and Portuguese, with the purpose of identifying the differences between them. It draws upon the concept of analogy introduced by Bynon (1993), and the methodology includes an 
analysis of a corpus comprised of 247 items obtained through the comparison of the aforementioned Romance languages. Two hypotheses were tested: first, that the rhizotonic past participles in Italian would be found predominantly in the second conjugation, diverging from Spanish and Portuguese, what was confirmed by the collected data; and second, that the rhizotonic past participles in Romance languages in the first conjugation would be predominantly innovations, what was also confirmed by the data. It was found that the main sources of the rhizotonic past participles in the Romance languages considered in this study are: the heritage from the Latin rhizotonic past participles; the incorporation of Latin adjectives; analogical change and analogical creations.

Keywords: Romance linguistics; morphology; verb; past participle; Portuguese; Spanish; Italian.

\section{Introdução}

Um aspecto interessante no âmbito do domínio românico é o processo de diferenciação das línguas românicas a partir do latim. Sempre se coloca como um desafio identificar as causas dessa diferenciação nos mais variados níveis linguísticos, uma vez que a atuação de fatores intralinguísticos e extralinguísticos nesse processo certamente não se deu da mesma maneira em cada nível.

No presente estudo, apresenta-se uma análise de dados referentes à morfologia verbal românica, mais especificamente, referentes aos particípios passados rizotônicos do italiano, do espanhol e do português. Esta análise tem como objetivos gerais (a) identificar em que aspecto essas três línguas se diferenciam quanto aos particípios passados rizotônicos e (b) discutir quais foram os processos que terão determinado as diferenças identificadas.

\section{0 particípio passado latino: uma breve revisão}

Segundo afirma Faria (1958, p. 157), o sistema verbal latino regular era composto de quatro paradigmas de conjugação: $1^{\text {a }}$ conjugação (com vogal temática $\bar{a}$ ), como em laudāre (laudo); $2^{\mathrm{a}}$ conjugação (com vogal temática $\bar{e}$ ), como em monēre (moněo); $3^{\mathrm{a}}$ conjugação (com vogal temática $\breve{l}$ ou $\breve{u}$ ou com consoante), como, respectivamente, em facěre (fač̆o), minuěre (minŭo) e dicěre (dico); e $4^{\mathrm{a}}$ conjugação (com vogal temática $\vec{\imath}$ ), como em audīre (aud̆̌o). 
No que se refere à história dos particípios passados latinos, Ernout (1953, p. 219-228) afirma que a função de particípio passado no latim era desempenhada por um antigo adjetivo verbal em *-to-. Esse adjetivo indicava que o sujeito possuía a qualidade expressa pelo verbo, seja em sentido ativo ("praticou a ação"), seja em sentido passivo ("sofreu a ação"): p. ex., homo potus ("homem que bebeu") e homo vulneratus ("homem que foi machucado"). O sufixo em questão era ligado diretamente à raiz verbal, sem sufixo e em sua forma reduzida. Nos casos em que a raiz terminava em consoante, havia a simples adjunção (cf. clepěre $($ clepo $) \rightarrow$ cleptus $)$, podendo ainda frequentemente haver perda de sufixo ou infixo (cf. apisci (apiscior) $\rightarrow$ aptus e rumpěre (rumpō) $\rightarrow$ ruptus). Nos casos em que a raiz terminava em vogal, o particípio apresentava vogal longa quando o verbo tinha perfeito em $-\bar{a} v \bar{l}\left(1^{\mathrm{a}}\right.$ conj.,

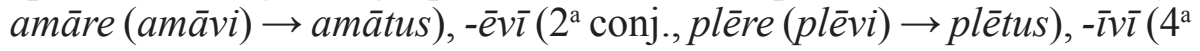
conj., audīre (audīvi) $\rightarrow$ audītus) e presente em -ŭō ( $3^{\mathrm{a}}$ conj., statŭere $($ statŭo $) \rightarrow$ statūtus); mas, quando tinha perfeito em -ū̄, apresentava vogal breve ( $1^{\mathrm{a}}$ conj., domāre (domu $\left.\vec{\imath}\right) \rightarrow$ domitus; $2^{\mathrm{a}}$. conj. monēre (monu $\left.\vec{\imath}\right) \rightarrow$ monitus; $3^{\mathrm{a}}$ conj. molëre (molu $\left.\bar{\imath}\right) \rightarrow$ molĭtus $)$ ou nenhuma vogal $\left(1^{\mathrm{a}}\right.$ conj., secāre $($ secū̄ $) \rightarrow$ sectus; e $3^{\text {a }}$ conj. docěre $($ docul̄ $) \rightarrow$ doctus $)$; também não apresentava nenhuma vogal, quando o verbo tinha presente em $-v \bar{o}$ ou -věo ( $\left(1^{\mathrm{a}}\right.$ conj., lavāre (lavō) $\rightarrow$ lautus; e $2^{\mathrm{a}}$ conj., movēre (mověō) $\rightarrow$ motus). Uma questão de interesse no quadro dos particípios passados latinos foi a extensão dos particípios em -sus. Um fenômeno fonológico em latim transformou as sequências $-t-$ ou $-d-+-t$ - em -ss-, fazendo coincidir a sibilante que já existia no perfeito com a recém-adquirida no particípio passado ( $2^{\mathrm{a}}$ conj., ridēre $($ risì $) \rightarrow$ risus; $3^{\mathrm{a}}$ conj., mittěre $($ miss $\vec{l}) \rightarrow$ missus). Esse modelo de perfeito e particípio em sibilante foi tomado como referência para uma mudança analógica, fazendo com que particípios cuja raiz não terminava em - $t$ - ou - $d$ - também tivessem terminação em -sus: isso atingiu verbos com raiz terminada em nasal (manēre $($ mansī $) \rightarrow$ mansus $)$, em -ct- $($ flectō $($ flexī $) \rightarrow$ flexus $)$, em velar (mergěre $($ mers $\bar{\imath}) \rightarrow$ mersus $)$ e no grupo -ll- (vellěre $($ vuls $\vec{~}) \rightarrow$ volsus $)$. A criação do particípio em -sus acabou atingindo diversos outros verbos, independentemente do tipo de consoante final da raiz ou da marca de perfeito: currĕre (cucurri) $\rightarrow$ cursus; censēre (censuī) $\rightarrow$ census; etc. Para a discussão dos particípios passados românicos, convém salientar que os particípios latinos poderiam ser arrizotônicos (com acento tônico fora da raiz) ou rizotônicos (com acento tônico na raiz): os primeiros 
aparecem nos particípios passados com vogal longa antes do morfema de particípio; os segundos, nos demais casos (particípios passados com vogal breve antes do morfema de particípio ou sem nenhuma vogal).

De acordo com Grandgent (1952, p. 265-268), o destino dos particípios passados no latim vulgar pode ser assim resumido: (a) verbos sem particípio passado inovaram criando-o ( *ferìtus para o verbo ferīre); (b) na $1^{\text {a }}$ conjugação, -ātus se conservou e se estendeu a todos os verbos (sectus $>$ secatus e domitus $>$ domatus); (c) na $3^{\text {a }}$ conjugação, -ātus desapareceu (oblatus > offertus); (d) na $4^{\text {a }}$ conjugação, -ìtus se conservou e se estendeu a quase todos os verbos (saltus $>$ salitus mas apertus e copertus), tendo ainda ocorrido a substituição de ventus por *venūtus; (e) na $2^{\mathrm{a}}$ conjugação, a desinência rara -ètus desapareceu, ficando apenas em formas adjetivais (complètus); (f) a terminação - $\bar{u} t u s$, dos verbos com infinitivo em -uere e-vere, se estendeu para os verbos com perfeito em -ū (habitus $>$ *habutus) e depois para outros verbos (creditus $>$ *credutus); (g) apesar da tendência de desaparecimento de -ľtus, houve algumas novas formações (*positus); (h) a terminação -tus se manteve em aproximadamente 20 verbos (dictus), com eventual mudança de acento (surrectus $>*$ surtus), havendo ainda algumas novas formações (visus $>$ *vīstus) ou substituições por -ätus (frictus $>$ fricatus), -ītus (saltus $>$ salitus) ou -ütus (tentus $>$ *tenutus); (i) a terminação -sus se conservou em geral (clausus), mas houve alguns verbos que a substituíram por - ̌̌tus (falsus $>*$ fallĭtus) e -ütus (visus $>*$ vidutus).

\section{Fundamentação teórica}

Como foi demonstrado na seção precedente, no curso da história do latim, houve uma competição entre formas rizotônicas (também chamadas de irregulares oufortes), p. ex., habitus/frictus, e arrizotônicas (também chamadas de regulares ou fracas), p. ex., *habūtus/fricātus. O principal processo por trás dessa competição é a chamada analogia.

\subsection{Analogia}

Segundo Bynon (1993, p. 32), a teoria neogramática, modelo que discutiu a atuação de analogia, alega fundamentalmente que a mudança fonológica, em níveis mais elevados (mais abstratos), possui uma total independência em relação a outros níveis linguísticos, tendo como 
consequência, no curso do tempo, uma dessintonia entre a estrutura gramatical e a estrutura fonológica. Esse desalinhamento entre as duas estruturas significa que as regras existentes anteriormente foram quebradas, tendo, assim, a possibilidade de demandar uma alteração e um reposicionamento nos estágios pelos quais a língua passa.

Para Bynon (1993, p. 34), a analogia e a mudança fonológica são consideradas dois componentes básicos da mudança linguística na teoria neogramática. Após mencionar esses dois processos, a autora explica que a analogia opera diretamente na relação entre a estrutura gramatical e a estrutura fonológica, em contraste com a mudança fonológica, que opera independentemente da estrutura gramatical e semântica. Bynon (1993, p. 34) estabelece ser esse, de fato, o próprio mecanismo da analogia, que, seja modificando formas linguísticas já existentes seja criando novas, traz de volta o alinhamento entre as formas fonológicas e a função gramatical, após a relação entre elas ter sido rompida pela mudança fonológica. Dessa forma, podem-se identificar dois tipos de formação analógica: mudança analógica e criação analógica. A mudança analógica produz o realinhamento de elementos em relação a uma categoria gramatical ou semântica sem gerar mais do que a redistribuição de seus elementos, mas a criação analógica produz novas formas ao estender uma correlação de forma e função existente para além de seu domínio original.

\subsection{A mudança analógica}

Bynon (1993, p. 35) explica que são necessárias duas condições para que a analogia aconteça: (a) pressupor a identidade funcional com relação a alguma categoria gramatical ou semântica específica (plural, substantivo agentivo, dativo) de marcadores formalmente distintos; e (b) pressupor que a estrutura da forma funciona como o modelo morfologicamente transparente para o falante nativo, o que sempre acontece com formas resultantes de regras produtivas. Bynon (1993, p. 35) aponta que a mudança consistirá na substituição da forma menos ou não mais transparente por uma forma de função equivalente cuja estrutura refletirá aquela do modelo. Como resultado, a segmentação morfológica do modelo será transferida para a forma, de maneira que o morfe representante da categoria compartilhada no modelo torne-se um de seus segmentos e os demais são tratados como a base ou uma nova base é criada nos padrões do modelo. Segundo Bynon (1993, p. 35) exemplifica, 
quando o marcador de plural -(e)s foi transferido da classe de stone para a classe de wound, este foi sufixado à única forma sobrevivente daquele paradigma, que foi reinterpretada como a base. De forma semelhante, em se tratando do número considerável de verbos fortes que migraram para a conjugação fraca, formas do passado em inglês, tais como holp, foram substituídas por novas formas regulares como helped, com base na seguinte análise do passado: "base (idêntica a radical do presente) + alveolar plosiva”, sendo automática a seleção da alternância. Como resultado desse tipo de analogia, mais da metade dos verbos sobreviventes que eram originalmente fortes passaram para a conjugação fraca desde o período do inglês antigo.

Bynon (1993, p. 35) explica que esse processo pode ter ocorrido gradualmente, com formas fracas sendo primeiramente desenvolvidas e utilizadas ao lado das formas fortes durante um período de tempo e, por fim, substituindo-as. Poucas formas fortes sobreviveram como o caso do verbo knew (e não knowed). Em comparação, novas formações fortes são extremamente raras, embora existam. Este é o caso do verbo to wear: wore, to spit: spat, to stick: stuck, to fling: flung, to dig: dug, to string: strung, e regionalmente no inglês americano to dive: dove. Tais verbos seguem o padrão dos verbos comuns originalmente fortes. Podese acrescentar a esse contexto o fato de que a mudança analógica operou não apenas entre as conjugações forte e fraca, mas também dentro da classe de verbos fortes propriamente dita, de modo que os verbos fortes sobreviventes raramente mantiveram a mesma forma esperada com base em pistas puramente fonológicas de uma comparação entre formas correspondentes no inglês antigo.

Bynon (1993, p. 36) explica que, como consequência dessas mudanças analógicas na morfologia de substantivos e de verbos, houve uma mera redistribuição dos morfes representantes de morfemas gramaticais específicos, ocasionando um declínio na incidência, ou seja, a frequência de ocorrência de morfes irregulares. Ao mesmo tempo, houve uma pequena redução no número total de alomorfes representantes desses morfemas. Dessa forma, embora o genitivo em $-s$ tenha sido generalizado para todos os substantivos em inglês e não haja mais o morfe zero como alternância, o plural em $-s$, por outro lado, ainda alterna com o morfe zero, $-n$ e mudança de vogal em alguns casos, como, por exemplo, sheep, oxen, women e, assim, os alomorfes irregulares não foram completamente eliminados. Isso se aplica de forma igual no caso das formas verbais 
do passado no inglês. Resta ainda um número significativo de verbos fortes e, consequentemente, o número total de alternantes do morfema de passado tem se mantido relativamente estável. Bynon (1993, p. 36) explica ainda que as mudanças não reduziram de forma substancial o número de regras necessárias para a formação do plural e do passado, não obstante tenham aumentado em grande escala a frequência dos alternantes regulares. Uma consequência mais decisiva dessas mudanças estaria no léxico, pois causaram uma redução substancial no número de raízes com alomorfia. Bynon (1993, p. 36) acrescenta que todos os itens lexicais transferidos para o padrão regular perderam seus alternantes irregulares e cada um veio a ser representado por um único morfe em seu paradigma. Os exemplos da formação de plural a seguir são os poucos substantivos que não levam o sufixo $-s$ : feet, teeth, geese, mice, lice, men, oxen, children, etc. Paralelamente, os alternantes irregulares ainda desempenham um papel importante em relação aos verbos (cerca de 80 em uso atualmente). Bynon (1993, p. 36) identifica duas facetas da mudança analógica: por um lado, produz o efeito regularizador na gramática ao eliminar alternantes gramaticais irregulares ou, pelo menos, diminuir sua frequência de ocorrência; por outro, reduz o número total de itens lexicais irregulares na língua.

Também é possível observar a mudança analógica de outro ângulo, a partir de seus efeitos na alternância morfológica, isto é, de acordo com o número e a forma dos alomorfes (ou alternantes) de morfemas individuais em paradigmas flexionados e padrões derivacionais (/ki:p/ /kep-/ em keep: kept, /gu:t/ /gü:t-/ em gut "bom": Güte "bondade"). Todos os casos de mudança analógica citados até o momento podem, sob esse ponto de vista, ser interpretados enquanto instâncias de nivelamento analógico, já que produziram o efeito de eliminar ou, ao menos, reduzir a alternância. Conforme Bynon (1993, p. 37), desde a sua transferência para a conjugação fraca, o verbo help passou a ter um único alternante helped, em vez de dois, representados por /help/e / $h$-lp/. Ainda segundo a autora, tais casos de eliminação da alternância no léxico teriam um efeito regularizador na língua, visto que os verbos que foram para a conjugação fraca não necessitam mais ser listados para um tratamento separado no que se refere à formação do passado. Pode-se dizer o mesmo para o morfema plural dos substantivos: a substituição de kine por cows aumentou a incidência do morfe plural regular e eliminou um alternante do léxico. Bynon (1993, p. 37) completa que a alternância, em 
alguns casos, não é completamente eliminada, mas apenas reduzida, ou seja, os alternantes se tornam mais similares sem, no entanto, alcançar uma identidade. Portanto, a palavra que designa "roda" no alemão protomoderno possuía os alternantes $/ \mathrm{ra}: \mathrm{d}$-/ e $/ \mathrm{rat} /$, que no alemão atual são /ra:d-/ e /ra:t/.

Afirma Bynon (1993, p. 37) que a mudança analógica pode também aumentar a alternância, a qual nesse caso é possível de ser tratada como extensão analógica de uma alternância que ultrapassa o seu domínio original. Via de regra, essa seria a mudança mais rara das duas. Para dar um exemplo familiar, Bynon (1993, p. 37) cita o caso da difusão do $r$ intrusivo em certas variedades do inglês britânico atual: (a) itens lexicais que apresentam uma alternância entre vogal em final de palavra e vogal $+r$ antes de vogal (car $/ k a: / \sim$ car of $/ k a$ :$r$-əv/); e (b) itens lexicais que passaram a partilhar dessa alternância após o processo de mudança analógica (law /lo:/ law of /lo:-r-əv/). A mudança analógica, portanto, criou a alternância utilizando $r$ no caso de palavras que, ao longo de sua história, não tinham esse $r$. Bynon (1993, p. 37) cita também exemplos de difusão analógica no alemão, casos em que o marcador de plural em -er acompanhado de Umlaut (metafonia) era considerado como base apenas de uma pequena classe nuclear. $\mathrm{O}$ espalhamento do sufixo -er afetou um grande número de substantivos neutros cujas formas de plural eram idênticas às formas do singular. Através do modelo de certas formas antigas como Kalb: Kälber e Lamm: Lämmer, inúmeros plurais com Umlaut foram criados com substantivos neutros como Wort: Wörter, Buch: Bücher, Kraut: Kräuter e até com um pequeno número de substantivos masculinos como Mann: Männer, Wald: Wälder. Segundo Bynon (1993, p. 38), a afixação de -er vem sempre acompanhada pelo Umlaut na vogal da raiz, de forma que a alternância da raiz com Umlaut e sem Umlaut se estendeu a itens lexicais que previamente não tinham essa alternância, resultando no aumento da uniformidade na formação do plural e, também, na frequência da alternância no léxico. Bynon (1993, p. 38) explica que a alternância nos itens lexicais não teve um aumento expressivo, visto que vários desses substantivos já possuíam uma alternância com Umlaut com finalidades derivacionais, por exemplo, na formação de diminutivo ou de adjetivo em -lich ou -ig. Enquanto o Umlaut é totalmente previsível no caso do plural em -er (Wort: Wörter), já nos processos derivacionais sua ocorrência é imprevisível: Wort, Wörtchen, wörtlich, mas Holz, Hölzchen, holzig; e Haus, häuslich, mas Gast, gastlich, entre outros. Bynon (1993, p. 38) explica ainda que, 
enquanto a formação do plural implica automaticamente em alternância, os processos derivacionais não necessariamente o fazem por ser de maior economia tratar cada processo morfológico como tendo uma regra de alternância ao invés de buscar atribuir uma regra para cada base lexical. Bynon (1993, p. 38) complementa dizendo, a respeito da extensão da alternância morfologicamente redundante, que considera, em termos de economia estrutural, um processo que não é de fácil explicação e, apesar desse caráter complexo, foi elevado ao status de princípio como uma forma mais completamente marcada que tende a se favorecer às custas de outras menos inteiramente marcadas.

Bynon (1993, p. 38) explica o fato de ter adotado a discussão sobre a morfologia flexional ao invés da morfologia derivacional. Comenta que, apesar das mudanças analógicas atingirem também a morfologia derivacional, isso ocorre em uma escala bastante limitada. Um dos motivos estaria no fato de que a alomorfia é uma regra menos claramente definida na morfologia derivacional, embora a mudança analógica pressuponha que alguma categoria semântica específica seja representada por dois ou mais elementos em competição, como, por exemplo, certos substantivos agentivos terminados em -er em alemão. Bynon (1993, p. 39) explica, ainda, que esse tipo de substantivo se espalhou na língua às custas de um tipo mais antigo que, após ser modificado pela mudança fonológica, seus membros se tornaram irreconhecíveis como classe. Para a representação da palavra padeiro em alemão, existia a forma Beck, que ainda sobrevive dialetalmente. Porém, foi substituída pelo substantivo agentivo Bäcker, formado a partir do verbo backen em analogia com pares de palavras como fischen: Fischer e graben: Gräber. Seguindo por um caminho paralelo, existem Trinker, Geber e Helfer, que substituíram as formas equivalentes mais antigas funcionalmente do antigo alto alemão: trinko, gebo e helfo. Segundo a autora, como resultado do processo de remodelamento e da produtividade contínua do sufixo -er, os substantivos agentivos que não se formaram com esse sufixo passaram a ser raros na língua alemã.

Bynon (1993, p. 39) afirma que os motivos pelos quais as mudanças analógicas ocorrem com menor frequência na morfologia derivacional do que na morfologia flexional devem ser investigados em diferenças gerais entre esses dois processos. As regras sintáticas de uma língua podem exigir que cada substantivo e verbo flexione para um específico número de categorias gramaticais, não existindo restrições 
comparáveis em relação a regras derivacionais: é geralmente imprevisível se um derivado específico ocorrerá ou não na língua; porém terão de ser listadas no léxico todas as formas derivadas. Além disso, enquanto as categorias gramaticais operativas nas regras sintáticas tendem a formar pequenas classes relativamente fechadas, as categorias semânticas envolvidas na derivação de novos itens lexicais são, em geral, em grande número, e cada uma envolve constantemente somente uma quantidade limitada de bases. É necessário adicionar o fato de que, no interior de cada conjunto derivacional caracterizado por um padrão formal específico, a relação semântica entre a base e a derivada não é idêntica em todos os contextos. Bynon (1993, p. 39) explica que, em razão do seu papel lexical primordial e sua participação limitada na sintaxe, as regras derivacionais estão muito menos sujeitas à mudança analógica do que à mudança flexional, justamente pelo fato de os dois componentes parecerem atuar bastante diferentemente um do outro, de maneira que, com certa frequência, acontece de uma alternância herdada sobreviver entre a base e a derivada, embora seja eliminada no paradigma flexional.

\subsection{A criação analógica}

Bynon (1993, p. 40) explica que, se a mudança analógica é o mecanismo fundamental através do qual mudanças morfológicas de um idioma são atualizadas, a criação analógica é o mecanismo que permite a renovação de recursos lexicais e conceituais. Para a autora, praticamente toda inovação não resultante de empréstimo é motivada, ou seja, formada, via de regra, a partir de formas pré-existentes. É o caso de palavras como measurable, reasonable, acceptable, agreeable, comfortable e profitable, que foram emprestadas do francês e incorporadas ao inglês médio. A base dessas palavras sem o sufixo também foi emprestada e incorporada em substantivos (measure, reason), verbos (accept, agree) ou ambos (comfort, profit) e, por isso, -able pode ser considerado um morfe com a função "capaz de/para..." ou "capaz de ser...". Esse padrão se tornou extremamente produtivo no inglês e, atualmente, a derivação -able é frequentemente utilizada para formar adjetivos, principalmente a partir de verbos (eatable, drinkable, machine washable, etc.). Segundo Bynon (1993, p. 40), uma possível razão para a popularidade desse padrão seria o fato de ele não provocar alternância morfológica na base. Exemplos mais modernos de criação analógica são os termos que 
nomeiam itens recentemente incorporados ao menu, como beefburger, cheeseburger, eggburger, baconburger e até mesmo burger. Todos esses termos resultaram de uma nova segmentação e reinterpretação semântica da palavra hamburger (que, na verdade, vem de Hamburg "Hamburgo"; e não de ham "presunto"). Também servem de exemplo palavras como townscape, seascape, beachscape e moonscape, criadas a partir do modelo da palavra landscape.

Bynon (1993, p. 40) define como marginal a distinção entre mudança analógica e criação analógica. Para a autora, tal distinção é típica de uma abordagem da língua baseada em corpus, segundo a qual todas as formas encontradas devem ser analisadas e explicadas. Se, no entanto, a língua é considerada a partir do seu aspecto criativo, que opera na competência de um falante conforme determinadas regras, essa divisão perde significado, pois as mesmas regras que geraram formas pré-existentes podem facilmente dar origem a novas formas. A autora esclarece que, em um modelo de linguagem baseado em regras, a criação analógica pode ser facilmente explicada, seja a partir de regras sincrônicas existentes, seja a partir de regras suscetíveis de existir na língua. Novas palavras como moonscape são imediatamente compreendidas porque são baseadas em uma regra latente que explica a palavra landscape.

Bynon (1993, p. 40) afirma que a morfologia flexional e a derivacional representam as áreas da gramática em que se podem mais facilmente observar os efeitos do princípio da analogia. A aplicação de padrões para além do seu domínio original é, no entanto, bem comprovada na sintaxe. A autora apresenta como exemplo o verbo lehren ("ensinar"), do alemão. Na fase mais antiga dessa língua, utilizavam-se dois acusativos (einen etwas lehren, "ensinar alguém algo"), mas, no alemão atual, a pessoa que sofre a ação pode também aparecer no dativo (einem etwas lehren, "ensinar a alguém algo"), presumidamente conforme a analogia com um número grande de verbos de três partes que têm um objeto dativo (einem etwas erzählen/zeigen/geben, etc. "dizer, mostrar, dar a alguém algo"). Outro exemplo provém do declínio constante na frequência de objetos do caso genitivo. Ainda se diz em alemão padrão: der Toten gedenken ("recordar os mortos"), einer Sache bedürfen ("precisar de algo"). Os objetos que acompanham esses verbos estão no genitivo, mas esses casos são raros e muitos outros verbos que exigiam um objeto genitivo no passado o substituíram por um acusativo (etwas vergessen/begehren/entbehren/ geniessen "esquecer, desejar, faltar, apreciar algo"). 


\section{Hipóteses de trabalho}

A língua latina tinha 4 paradigmas de conjugação verbal, que foram reduzidos a 3 no italiano, no espanhol e no português. Entretanto, há uma especificidade que diferencia o primeiro dos dois últimos. A $3^{\mathrm{a}}$ conjugação latina, em função do sistema acentual dessa língua, apresentava infinitivo rizotônico, em contraste com a $1^{\mathrm{a}}, 2^{\mathrm{a}}$ e $4^{\mathrm{a}}$ com infinitivo arrizotônico de forma geral. No italiano, a $2^{\mathrm{a}}$ e a $3^{\mathrm{a}}$ conjugação latina fundiram-se formando a $2^{\mathrm{a}}$ conjugação italiana, mantendo infinitivos arrizotônicos (paroxítonos) e rizotônicos (proparoxítonos), mas, no espanhol e no português, a fusão formando a $2^{\mathrm{a}}$ conjugação respectiva resultou na manutenção de infinitivos apenas arrizotônicos (paroxítonos). Pode-se, assim, hipotetizar que os particípios passados rizotônicos no italiano estejam predominantemente na $2^{a}$ conjugação, diferentemente do espanhol e do português, pois a manutenção de infinitivo rizotônico (proparoxítono) no primeiro deve ter favorecido a manutenção e a criação de particípios passados rizotônicos nessa mesma língua.

Além disso, no latim, os particípios passados rizotônicos eram muito raros e geralmente se tornaram arrizotônicos no latim vulgar: pode-se, por isso, hipotetizar que, no italiano, no espanhol e no português, os particípios passados rizotônicos da $1^{a}$ conjugação sejam predominantemente criações analógicas que constituem inovações românicas.

\section{Metodologia}

Para realizar a análise comparativa dos particípios passados rizotônicos no italiano, no espanhol e no português, foi feita uma coleta de dados a fim de constituir um corpus a partir do qual se possam realizar interpretações para o tema.

O corpus para análise foi formado a partir de consulta a diferentes gramáticas de cada língua em questão. ${ }^{1}$ Para avaliar a hipótese relativa às

\footnotetext{
${ }^{1}$ Italiano: Peccianti (1993); Diaco e Kraft (2003); Conforti e Cusimano (2005); Chiuchiù, Fazi e Bagianti (2007); Bailini e Consonno (2004); Marin e Magnelli (2010); Nocchi (2011); Birello e Vilagrasa (2012); Chiuchiù e Chiuchiù (2012); Trifone $\mathrm{e}$ Palermo (2014) / Espanhol: Real Academia Española (1928); Ballesteros e Sordo (2005); Martins e Pacheco (2005); Raya et al. (2005); Moreno et al. (2007); Ainciburu et al. (2011); Torrego (2011) / Português: Pereira (1945); Reis (1978); Lobato (1999); Cunha e Cintra (2007); Bechara (2009); Cunha (2010); Perini (2010).
} 
inovações românicas fez-se necessário relacionar as formas de particípio passado nas línguas românicas em questão com as formas latinas.

Mais concretamente, a coleta de dados foi feita com o registro de todas as formas de particípio passado rizotônico e respectivos infinitivos apresentados nas obras consultadas para o italiano, o espanhol e o português; e com a identificação da forma etimológica latina relacionada às formas românicas registradas.

\section{Descrição e discussão dos dados}

\subsection{Visão geral}

Com base no método de coleta de dados descrito, foi possível constituir uma lista de 247 itens relevantes.

Um primeiro aspecto a ser considerado é a existência de formas correlatas entre as três línguas românicas consideradas. Em 194 casos $(78,5 \%)$, há forma correlata em italiano, em espanhol e em português ( $\mathrm{p}$. ex., it. muovere /mosso; esp./port. mover/movido). Em 10 casos (4\%), há apenas entre italiano e português (p. ex., it. aggiungere/aggiunto; port. adjungir/adjungido). Em 27 casos (10,9\%), apenas entre espanhol e português (p. ex., esp. encubrir/encubierto; port. encobrir/encoberto). Em 10 casos (4\%), há forma relevante apenas no italiano (p. ex., it. uccidere/ ucciso). E, por fim, em 6 casos $(2,4 \%)$, há forma relevante apenas no português (p. ex., port. safar/safado-safo).

Um segundo aspecto é a questão da existência de correspondência com forma infinitiva latina dicionarizada. Convém esclarecer que, em relação a esse aspecto, há duas possibilidades: correspondência plena (as formas das três línguas românicas têm correspondência com uma forma latina dicionarizada, como lat. v̌̈dēre/visum, it. vedere/visto-veduto e esp./port. ver/visto) ou correspondência parcial (uma ou duas línguas românicas têm correspondência com uma forma latina dicionarizada, mas a(s) outra(s) não, como lat. finīre/finitum, it. finire/finito e esp. finir/ finido mas port. findar/findado, com forma infinitiva hipotética *finitāre derivada do particípio passado finitum). Os resultados podem ser melhor visualizados na tabela abaixo: 
Tabela 1 - Tipos de correspondência das formas infinitivas do corpus

\begin{tabular}{l|c|c|c|c}
\hline $\begin{array}{c}\text { Tipo de } \\
\text { correlação }\end{array}$ & $\begin{array}{c}\text { Com correspondência } \\
\text { latina plena }\end{array}$ & $\begin{array}{c}\text { Com correspondência } \\
\text { latina parcial }\end{array}$ & $\begin{array}{c}\text { Sem correspondência } \\
\text { latina }\end{array}$ & Total \\
\hline I-E-P & 154 & 8 & 32 & 194 \\
I-P & 9 & 0 & 1 & 10 \\
E-P & 10 & 0 & 17 & 27 \\
I & 7 & 0 & 3 & 10 \\
P & 2 & 0 & 4 & 6 \\
Total & $\mathbf{1 8 2}$ & $\mathbf{8}$ & $\mathbf{5 7}$ & $\mathbf{2 4 7}$ \\
\hline
\end{tabular}

Legenda: $\mathrm{I}=$ italiano, $\mathrm{E}=$ espanhol, $\mathrm{P}$ = português. A correção I-E-P significa que existência de formas correlatas nas três línguas em questão; já I-P e E-P significam existência dessa correlação entre apenas cada uma das duas em questão; por fim, I e P indicam formas privativas da língua em questão.

Uma primeira questão que se pode avaliar é se os particípios passados rizotônicos românicos têm relação com o seu paradigma de conjugação. Como foi sugerido na primeira hipótese de trabalho deste estudo, o italiano teria mais particípios passados rizotônicos na $2^{\mathrm{a}}$ conjugação do que o espanhol e o português por ter mantido infinitivos rizotônicos nessa conjugação.

Tabela 2 - Particípios passados rizotônicos românicos por paradigma de conjugação ${ }^{2}$

\begin{tabular}{|c|c|c|c|}
\hline \multirow{2}{*}{ Conjugação } & \multicolumn{3}{|c|}{ Idioma } \\
\hline & Italiano & Espanhol & Português \\
\hline $1^{\text {a }}$ conjugação & $6(4 \%)$ & $8(12,5 \%)$ & $77(36,6 \%)$ \\
\hline $\begin{array}{l}2^{\mathrm{a}} \text { conjugação } \\
\text { (infinitivo arrizotônico) }\end{array}$ & $4(2,7 \%)$ & $33(51,6 \%)$ & $66(31,4 \%)$ \\
\hline $\begin{array}{l}2^{\mathrm{a}} \text { conjugação } \\
\text { (infinitivo rizotônico) }\end{array}$ & $122(81,9 \%)$ & - & - \\
\hline $3^{\text {a } \text { conjugação }}$ & $17(11,4 \%)$ & $23(35,9 \%)$ & $67(31,9 \%)$ \\
\hline Total & $149(100 \%)$ & $64(100 \%)$ & $210(100 \%)$ \\
\hline
\end{tabular}

\footnotetext{
${ }^{2}$ Em seis casos do português, há dois particípios passados rizotônicos: aceitar/aceitadoaceito-aceite; cativar/cativado-cativo-capto; cozer/cozido-cozeito-coito; assentar/ assentado-assento-assente; extremar/ extremado-extreme-extremo.
} 
Os dados da Tabela 2 acima confirmam a hipótese de que o italiano tem mais particípios passados rizotônicos na $2^{\mathrm{a}}$ conjugação do que o espanhol e o português. Isso serve de evidência para o postulado de que o italiano apresenta mais particípios passados rizotônicos na $2^{\mathrm{a}}$ conjugação porque manteve infinitivos rizotônicos.

A tabela permite verificar, no entanto, que, embora o italiano tenha mais particípios passados rizotônicos na $2^{\mathrm{a}}$ conjugação, não é, dentre as línguas analisadas, a que mais apresenta esse tipo de forma, mas sim o português.

Levando adiante a discussão dos dados, convém salientar que há três tipos relevantes de situação para a análise das línguas românicas: presença apenas de particípio passado arrizotônico (A), apenas de rizotônico $(\mathrm{R})$ ou de dois ou mais particípios, caso em que geralmente há um arrizotônico e outro(s) rizotônico(s) $(\mathrm{AR})^{3}$. O cruzamento desse aspecto com a tabela acima permitirá verificar qual é a relação entre os particípios passados arrizotônicos latinos e românicos.

${ }^{3}$ É raro no corpus caso de dois particípios passados arrizotônicos ao lado de um rizotônico. Há apenas o seguinte caso no português: absolver/absolvido-absolutoabsolto. Dados como o do português manter/mantido-manteúdo não fazem parte do corpus por não apresentarem particípios passados rizotônicos. 
Tabela 3 - Formas de particípio passado do corpus com correspondência latina plena

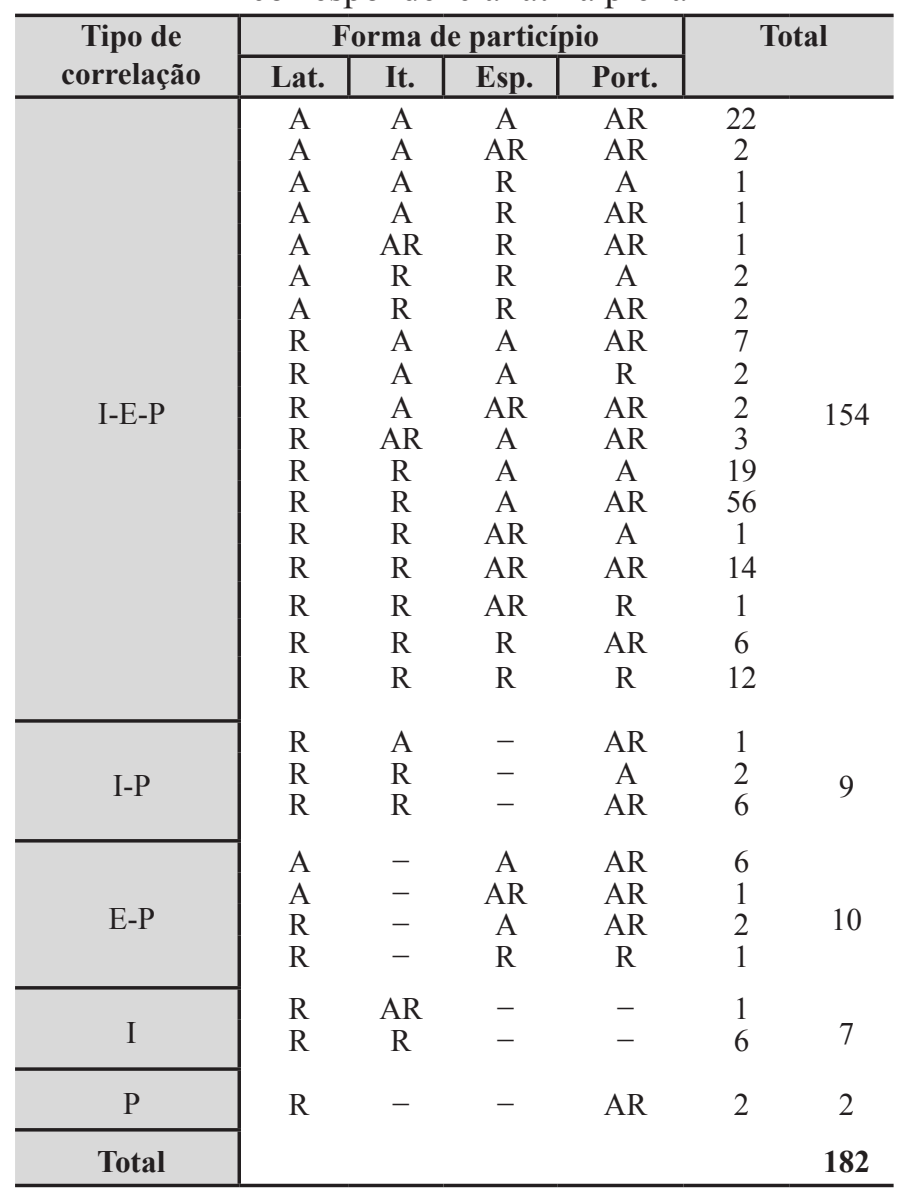

A tabela acima evidencia que a história dos particípios passados rizotônicos românicos é bastante complexa, uma vez que os padrões resultantes no caso de formas infinitivas com correspondência latina plena são muito variados.

Para responder à questão da relação entre os particípios passados rizotônicos latinos e românicos, é necessário extrair dados da referida Tabela 3. Considerando os 154 itens do padrão I-E-P, verifica-se que há 123 itens em que já no latim havia particípio passado rizotônico (cf. categorias com R na coluna do latim). 
Nesses 123 itens com particípio passado latino rizotônico, em 90 tem-se efetivamente apenas a continuação histórica (com as respectivas mudanças fônicas) da forma latina rizotônica no italiano (p. ex., lat. tingěre/tinctum e it. tingere/tinto). Em 19 há apenas forma rizotônica italiana diferente da latina (p. ex., lat. proevidēre/provisum e it. prevedere/ previsto). Em 3, tem-se no italiano a continuação histórica da forma latina rizotônica e também a criação de uma nova forma arrizotônica (p. ex., lat. insěrěre/insertum e it. inserire/inserito-inserto). Em 11, há a substituição da forma rizotônica latina por uma arrizotônica no italiano (p. ex., lat. věnīre/ventum e it. venire/venuto).

Enfim, de 123 casos de particípio passado rizotônico no latim, $93(75,6 \%)$ tiveram continuação histórica no italiano (sozinhos ou com forma arrizotônica paralela), o que permite dizer que o italiano apresenta alta taxa de retenção de particípios passados rizotônicos de origem latina.

Nos referidos 123 itens com particípio passado latino rizotônico, em 16 tem-se efetivamente apenas a continuação histórica (com as respectivas mudanças fônicas) da forma latina rizotônica no espanhol (p. ex., lat. rŭmpěre/ruptum e esp. romper/roto). Em 2 há apenas forma rizotônica espanhola diferente da latina (p. ex., lat. proevidère/provisum e esp. prever/ previsto). Em 16, tem-se no espanhol a continuação histórica da forma latina rizotônica e também a criação de uma nova forma arrizotônica (p. ex., lat. tingěre/tinctum e esp. teñir/teñido-tinto). Em 87, há a substituição da forma rizotônica latina por uma arrizotônica (p. ex., lat. věnīre/ventum e it. venir/venido). Em 2 há uma forma rizotônica espanhola diferente da latina e ainda a criação de uma nova forma arrizotônica (p. ex., lat. extenděre/extentum e esp. extender/extenso-extendido).

Enfim, de 123 casos de particípio passado rizotônico no latim, 32 (26\%) tiveram continuação histórica no espanhol (sozinhos ou com forma arrizotônica paralela), o que permite dizer que o espanhol apresenta baixa taxa de retenção de particípios passados rizotônicos de origem latina.

Nos referidos 123 itens com particípio passado latino rizotônico, em 11 tem-se efetivamente apenas a continuação histórica (com as respectivas mudanças fônicas) da forma latina rizotônica no português (p. ex., lat. sătisfăcĕre/satisfactum e port. satisfazer/satisfeito). Em 4 há apenas forma rizotônica portuguesa diferente da latina (p. ex., lat. prcevidēre/provisum e port. prever/previsto). Em 83, tem-se no português a continuação histórica da forma latina rizotônica e também a criação de uma nova forma 
arrizotônica $^{4}$ (p. ex., lat. tingěre/tinctum e port. tingir/tingido-tinto). Em 20, há a substituição da forma rizotônica latina por uma arrizotônica (p. ex., lat. mŏvēre/motum e port. mover/movido). Em 5 há forma rizotônica portuguesa diferente da latina e ainda a criação de uma nova forma arrizotônica ${ }^{5}$ ( . $^{2}$ ex., lat. tenděre/tentum e port. tender/tenso-tendido).

Enfim, de 123 casos de particípio passado rizotônico no latim, 94 (76,4\%) tiveram continuação histórica no português (sozinhos ou com forma arrizotônica paralela), o que permite dizer que o português também apresenta alta taxa de retenção de particípios passados rizotônicos de origem latina.

Os dados apurados acima mostram uma situação curiosa: espanhol tem baixa taxa de retenção de particípios passados rizotônicos de origem latina $(26 \%)$, mas italiano e português apresentam alta taxa (respectivamente,75, 6\% e 76,4\%); no entanto, italiano e português se diferenciam quanto à situação da forma rizotônica de origem latina: no primeiro, é predominantemente como particípio único $(90 / 123=73,2 \%)$, mas, no segundo, o é com mais de um particípio $(83 / 123=67,5 \%)$, geralmente duplo e eventualmente triplo.

Veja-se agora a relação entre os particípios passados arrizotônicos latinos do corpus e os românicos correspondentes. Considerando os 154 itens do padrão I-E-P, verifica-se que há 31 em que já no latim havia particípio passado arrizotônico (cf. categorias com A na coluna do latim).

No italiano, em 26 itens há apenas a forma arrizotônica: nesses casos tem-se efetivamente a continuação histórica da forma latina ( $\mathrm{p}$. ex., lat. acceptāre/acceptatum e it. accettare/accettato). Em 4 itens há particípio passado arrizotônico no latim e há rizotônico no italiano (p. ex., lat. absolvěre/absolutum e it. assolvere/assolto). Em 1, tem-se no italiano a continuação histórica da forma latina arrizotônica e também a criação de uma nova forma rizotônica (p. ex., lat. volvěre/volūtum e it. volgere-volvere/voluto-volto).

No espanhol, em 22 itens há apenas forma arrizotônica: nesses casos tem-se efetivamente a continuação histórica da forma latina ( $\mathrm{p}$. ex., lat. acceptāre/acceptatum e esp. aceptar/aceptado). Em 7, há a

\footnotetext{
${ }^{4}$ Em um caso a mesma forma rizotônica latina deu origem a duas rizotônicas portuguesas: lat. nasci/natus e port. nascido/nado-nato. A forma nato sugere possível origem erudita para alguns rizotônicos.

${ }^{5}$ Em um caso, há uma arrizotônica e ainda duas formas rizotônicas no português, todas distintas da latina: lat. coquĕre-cŏcĕre/coctum e port. cozer/cozido-cozeito-coito.
} 
substituição da forma arrizotônica latina por uma rizotônica (p. ex., lat. absolvěre/absolutum e esp. absolver/absuelto). Em 2, tem-se a continuação histórica da forma latina arrizotônica e também a criação de uma nova forma rizotônica (p. ex., lat. mănŭfestāre/manifestatum e esp. manifestar/manifestado-manifiesto).

No português, em 24 itens tem-se a continuação histórica da forma latina arrizotônica e também a criação de uma nova forma rizotônica ${ }^{6}$ (p. ex., lat. mănüfestāre/manifestatum e port. manifestar/manifestado-manifesto). Em 1, tem-se a continuação histórica da forma latina arrizotônica e também a criação de uma nova forma arrizotônica e outra rizotônica (p. ex., lat. absolvěre/absolūtum e port. absolver/absoluto-absolvido-absolto). Em 3, tem-se a criação de uma nova forma arrizotônica e outra rizotônica (p. ex., lat. involvěre/involütum e port. envolver/envolvido-envolto). Em 4 tem-se a continuação histórica da forma latina arrizotônica e também a criação de uma outra forma arrizotônica (p. ex., lat. devolvěre/devolūtum e port. devolver/devoluto-devolvido).

Os dados apurados acima mostram um padrão comum: as três línguas apresentam alta taxa de retenção de particípios passados arrizotônicos de origem latina (italiano, 27/31 = 87,1\%; espanhol, 24/31 $=77,4 \%$; português, $29 / 31=93,5 \%$ ), embora o português apresente a mais alta taxa de retenção.

Não se fará aqui análise pormenorizada das demais categorias (I-P, E-P, I e P) do corpus com correspondência latina plena, porque apresentam muito poucos dados, tornando desaconselháveis as generalizações. $\mathrm{O}$ mesmo se aplica aos poucos casos de correspondência latina parcial da categoria I-E-P. Embora não sejam analisados detidamente aqui, sua existência é digna de nota para salientar a complexidade da evolução histórica dos particípios passados latinos para as línguas românicas.

Uma vez discutidos os dados referentes aos particípios passados latinos rizotônicos e arrizotônicos nos casos de presença de forma correlata no italiano, no espanhol e no português com correspondência latina plena, podem-se considerar esses aspectos em casos sem correspondência latina, conforme a tabela abaixo:

\footnotetext{
${ }^{6}$ Em dois casos, há uma arrizotônica herdada e ainda duas formas rizotônicas no português, ambas distintas da latina: lat. acceptāre/acceptatum e port. aceitar/aceitadoaceito-aceite; lat. captivāre/captivatum e port. cativar/cativado-cativo-capto.
} 
Tabela 4 - Formas de particípio passado do corpus sem correspondência latina

\begin{tabular}{|c|c|c|c|c|c|c|}
\hline \multirow{2}{*}{$\begin{array}{c}\text { Tipo de } \\
\text { correlação }\end{array}$} & \multirow{2}{*}{ Idiomas } & \multicolumn{3}{|c|}{ Forma de particípio } & \multirow{2}{*}{\multicolumn{2}{|c|}{ Total }} \\
\hline & & It. & Esp. & Port. & & \\
\hline \multirow{10}{*}{ I-E-P } & \multirow{8}{*}{ IT./ESP./PORT. } & A & A & $\mathrm{AR}$ & 18 & \\
\hline & & A & AR & $\mathrm{AR}$ & 1 & \\
\hline & & A & $\mathrm{R}$ & $\mathrm{AR}$ & 1 & \\
\hline & & $\mathrm{R}$ & A & $\mathrm{AR}$ & 1 & \\
\hline & & $\mathrm{R}$ & A & A & 1 & 30 \\
\hline & & $\mathrm{AR}$ & $\mathrm{AR}$ & $\mathrm{AR}$ & 1 & \\
\hline & & $\mathrm{R}$ & $\mathrm{R}$ & AR & 2 & \\
\hline & & $\mathrm{R}$ & $\mathrm{R}$ & $\mathrm{R}$ & 5 & \\
\hline & \multirow[b]{2}{*}{ IT. × ESP./PORT. } & $\mathrm{R}$ & A & A & 1 & \\
\hline & & A & A & $\mathrm{AR}$ & 1 & 2 \\
\hline I-P & \multirow[t]{2}{*}{ IT./ PORT. } & $\mathrm{R}$ & - & $\mathrm{AR}$ & 1 & 1 \\
\hline \multirow{3}{*}{ E-P } & & - & A & $\mathrm{AR}$ & 10 & \\
\hline & \multirow{2}{*}{ ESP./PORT. } & - & AR & $\mathrm{AR}$ & 5 & 17 \\
\hline & & - & $\mathrm{R}$ & $\mathrm{R}$ & 2 & \\
\hline \multirow[b]{2}{*}{ I } & \multirow[b]{2}{*}{ IT. } & $\mathrm{R}$ & - & - & 1 & \\
\hline & & A & - & - & 2 & 3 \\
\hline $\bar{P}$ & \multirow[t]{2}{*}{ PORT. } & \multirow[t]{2}{*}{-} & \multirow[t]{2}{*}{-} & \multirow[t]{2}{*}{$\mathrm{AR}$} & \multirow[t]{2}{*}{4} & 4 \\
\hline Total & & & & & & 57 \\
\hline
\end{tabular}

Novamente, os dados mostram como a história dos particípios passados rizotônicos românicos é complexa, uma vez que os padrões resultantes no caso de formas infinitivas sem correspondência latina são muito variados.

Quando se levam em conta as três línguas românicas em questão, há 32 dados pertinentes. Em 30 deles, parece claro que as formas românicas têm, para cada caso, a mesma origem. Essa convergência na origem parece apontar para a existência de uma mesma forma latina de origem não documentada, embora não seja impossível haver casos de inovação comum. A etimologia das formas românicas apresentada nas obras consultadas assume, por vezes, a hipótese de origens diversas com resultados comuns: p. ex., a forma infinitiva latina complère não é postulada como fonte direta para as formas românicas correspondentes (it. completare; esp./port. completar), pois, para o italiano, atribui-se 
como fonte a forma francesa compléter e, para o espanhol e português, uma derivação sufixal a partir da forma românica completo. Por que não se atribuiu a derivação como fonte para as três? De forma geral, os itens em questão situam-se na $1^{\text {a }}$ conjugação (23 casos do italiano, 21 do espanhol e 20 do português) ${ }^{7}$. Sendo assim, seria de esperar que os particípios passados românicos respectivos fossem essencialmente arrizotônicos (como é comum nesse paradigma). Entretanto, não é isso que se constata, a partir da análise dos dados.

No padrão I-E-P/ IT.-ESP.-PORT./A-A-R, de 18 itens, 17 são da $1^{\text {a }}$ conjugação nas três línguas: no italiano e no espanhol, há, como esperado, apenas formas arrizotônicas, mas no português há também em todos eles uma forma rizotônica ${ }^{8}$ : p. ex., it. situare/situato, esp. situar/ situado e port. situar/situado-sito. No padrão I-E-P/ IT.-ESP.-PORT./AAR-R, o único item é de $1^{\text {a }}$ conjugação: no italiano há, como esperado, forma arrizotônica, mas no espanhol e no português há também uma forma rizotônica: p. ex., it. giuntare/giuntato e esp./port. juntar/juntadojunto. No padrão I-E-P/ IT.-ESP.-PORT./AR-AR-AR, o único item é de $1^{a}$ conjugação: no italiano, no espanhol e no português há uma forma arrizotônica e outra rizotônica: p. ex., it. confessare/confessato-confesso, esp. confesar/confesado-confeso e port. confessar/confessado-confesso. Esses dados, à primeira vista, sugeririam que os particípios passados rizotônicos não seriam simplesmente resquícios latinos: são frutos de processos românicos de formação. Mas, nos três exemplos acima, as formas rizotônicas em questão apresentam correspondência com os particípios latinos das formas que serviram de base para os derivados românicos: o verbo latino š̄něre tinha como particípio passado situm (fonte para os infinitivos românicos correspondentes formados por derivação sufixal); iungĕre tinha particípio iunctum; e confitēri tinha particípio passado confessus sum.

Essa correspondência sugere, então, uma nova linha de análise: seriam todos os particípios passados rizotônicos românicos simplesmente

\footnotetext{
${ }^{7}$ A diferença no número de casos em questão se deve ao fato de um mesmo verbo correlato se situar em diferentes conjugações românicas: cf. it. morire e esp. morir ( $3^{\mathrm{a}}$ conj.) x port. morrer $\left(2^{\mathrm{a}}\right.$ conj.); it. contraffare $\left(1^{\mathrm{a}}\right.$ conj.) $\mathrm{x}$ esp. contrahacer e port. contrafazer ( $2^{\mathrm{a}}$ conj.).

${ }^{8}$ Em um dos casos do português, há duas rizotônicas: extremar/extremado-extremeextremo.
} 
heranças latinas, ou seja, mesmo que não fossem herança do verbo que teve continuação histórica nas línguas românicas, seriam de outros verbos que desapareceram, mas deram origem a derivados (tratar-se-ia, portanto, de casos de supletivismo ${ }^{9}$ ). Para avaliar essa nova hipótese, convém verificar a etimologia de todos os particípios passados rizotônicos românicos da base de dados deste estudo.

Dos 247 itens do corpus, 214 têm dados referentes ao italiano (categorias I-E-P, I-P e I, independentemente do tipo de correspondência com o latim). Dentre esses 214, 149 apresentam uma ou mais formas rizotônicas (144 com apenas forma rizotônica e $5 \mathrm{com}$ forma rizotônica e forma arrizotônica). Desses 149 itens, em 104 casos o particípio passado rizotônico italiano deriva claramente do particípio passado rizotônico latino correspondente (p. ex., lat. risum e it. riso). Os demais 45 podem ser distribuídos em 6 grupos.

O primeiro grupo (7 itens), todos com correspondência latina, se refere aos relacionados ao particípio passado arrizotônico latino da

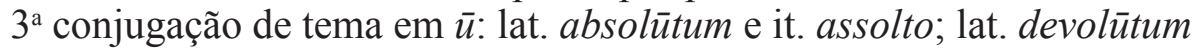
e it. devolto; lat. dissolūtum e it. dissolto; lat. exsolūtum e it. sciolto; lat. resolūtum e it. risolto; lat. revolūtum e it. rivolto; lat. volütum e it. volto. Para esse grupo, Grandgent (1933, p. 154) sugere ter havido uma reestruturação: volūtus $>$ volvĭtus $>$ volto. Embora o autor não o tenha dito de forma explícita, infere-se que o verbo de $3^{\text {a }}$ conjugação de tema em $\bar{u}$ tenha sido reestruturado como de tema em consoante (cf. lat. compōnĕre/compoš̆tum).

O segundo grupo (19 itens, alguns com correspondência latina e outros não), refere-se aos relacionados à generalização dos morfemas de particípios -to e -so. São formas com correspondência no latim: lat. accorrectum e it. accorto; lat. collectum e it. colto; lat. convulsum e it. convelto; lat. remansum e it. rimasto; lat. responsum e it. risposto; lat. surrectum e it. sorto; lat. visum e it. visto; lat. provisum e it. previsto; lat. provisum e it. provvisto; lat. attentum e it. atteso; lat. motum e it. mosso; lat. remotum e it. rimosso; lat. redditum e it. reso; lat. subtentum e it. sotteso; lat. perditum e it. perso. Formas sem correspondência no

\footnotetext{
${ }^{9}$ Supletivismo é um processo em que um paradigma acolhe formas de outro paradigma: na história do português, um caso clássico é o do verbo ir que apresenta formas derivadas dos verbos latinos ire, como port. ides ( $<$ lat. itis), e do vadere, como port. vou $(<$ lat. vado).
} 
latim: it. scegliere/scelto da hipotética latina ex + elügěrelelectum; it. nascondere/nascosto derivaria da forma hipotética latina in + abscōnděre/ abscōnditum; o it. offrire/offerto da hipotética latina offerire, relacionada à forma latina offěrre/oblatum; soffrire/sofferto da hipotética latina sufferire, relacionada à forma latina suffěrre/sustentum. Grandgent (1933, p. 154) esclarece que os particípios dos tipos -so e -to sofreram extensão: abscondĭtus > asconso/ascosto; mōtus > mosso; quaesītus > chięsto; latus $>$ tolto; vīsus $>$ visto (e vedúto). No latim, a forma básica de particípio era *to, mas, quando a raiz do verbo terminava em dental, havia um processo fônico que o transformava em * so: cf. ridere/risum $(<$ *rid-tos) (ERNOUT, 1953, p. 226). Ainda no latim, houve um processo de generalização dessa segunda forma para verbos que não tinham dental na raiz (cf. mergěre/mersum, fallěre/falsum, etc.). Essa generalização é uma mudança analógica, pois toma o paradigma dos verbos de raiz em consoante e o estende para outros paradigmas. Veja-se que, neste caso, a analogia não estaria diminuindo subparadigmas, mas apenas transferindo do paradigma em -to para o paradigma em -so, apesar de aquele ser muito mais generalizado do que este. Haveria efetiva regularização se todos os verbos pertinentes ( $3^{\text {a }}$ conjugação latina/ $2^{\text {a }}$ conjugação italiana) terminados em dental tivessem adotado o morfema -so, o que não aconteceu: há verbos com -so sem dental (it. comprimere/compresso) e com dental sem -so (it. pendere/penduto).

O terceiro grupo (2 itens), com correspondência latina, refere-se aos relacionados originariamente a adjetivos no latim: lat. tensum (adj.) e it. teso; e lat. extensum (adj.) e it. esteso.

O quarto grupo (3 itens), sem correspondência latina, refere-se a casos de supletivismo (incorporação de particípios de outros verbos): lat. confitêri/confessus sum, mas it. confessare (infinitivo diferente do latino)/confesso (particípio igual ao latino); lat. mŏri/mortus sum, mas it. morire/morto; e lat. requirěre/requisitum, mas it. acquisire/acquisito. É de se notar que neste grupo as formas infinitivas derivadas inovadoras têm como base o infinitivo que está associado ao particípio que adota.

O quinto grupo (7 itens), sem correspondência latina, são derivados prefixais de formas com correspondência latina: it. contraffatto, disfatto e rifatto (cf. lat. factum e it. fatto); it. riaperto (cf. lat. apertum 
e it. aperto); it. disdetto (cf. lat. dictum e it. detto); it. sorpreso (cf. lat. prensum e it. preso); e it. disinvolto (cf. lat. volütum e it. voluto-volto) ${ }^{10}$. O sexto grupo ( 7 itens), todos com correspondência latina, se refere aos relacionados ao particípio passado arrizotônico latino da $3^{a}$ conjugação de tema em consoante com raiz terminada em $-k$ : lat. convictum e it. convinto; lat. depictum e it. dipinto, lat. expictum e it. spinto/spento; lat. fictum e it. finto; lat. victum e it. vinto, lat. refractum e it. rifranto ${ }^{11}$. Não há informação sobre esse grupo em Grandgent (1933), mas pode-se hipotetizar que tenha sofrido influência de outro processo: em vez de o grupo - $k t$ - resultar em - $t t$ - como era a regra geral (cf. lat. frictum e it. fritto), resultou em - nt- como era regra geral para o grupo -nkt- de origem (lat. tinctum e o it. tinto).

Em síntese, embora a grande maioria dos particípios rizotônicos italianos seja efetivamente herança de particípios latinos correspondentes $(104 / 149=69,8 \%)$, os demais $(45 / 149=30,1 \%)$ não o são. Entretanto, grande parte desses 45 itens no italiano apresenta particípio passado rizotônico originado de particípio passado rizotônico latino diferente, tendo sido modificado por processos analógicos (como generalização de -to e -so, derivação prefixal, etc.) ou adotado por supletivismo (de adjetivos e de particípios de outros verbos latinos): apenas 7 itens (os de $3^{\text {a }}$ conjugação de tema em $\bar{u}$ ) eram originariamente arrizotônicos. Podese dizer, portanto, que, no italiano, quase todas as formas rizotônicas têm origem latina, sejam as herdadas das correspondentes latinas (as que passaram apenas por mudanças fonéticas) sejam as não herdadas das correspondentes latinas (as que passaram por processo analógico ou foram tomadas de outros paradigmas ou classes).

Dos 247 itens do corpus, 221 tem dados referentes ao espanhol (categorias I-E-P e E-P, independentemente do tipo de correspondência com o latim). Dentre esses 221, 64 apresentam uma ou mais formas

\footnotetext{
${ }^{10}$ A derivação desse verbo a partir do it. involvere coloca problemas: se derivação é simplesmente prefixação, então o particípio derivado deveria ser *desinvoluto e não desenvolto (cf. it. involvere/involuto)... Exceto se houve uma forma rizotônica *involto não documentada pelos gramáticos consultados.

${ }^{11} \mathrm{O}$ verbo rifrangere do italiano apresenta dois particípios passados rizotônicos: rifratto e rifranto. O primeiro apresenta a forma fonética esperada para a evolução a partir do lat. refractum; já o segundo apresenta uma nasal inesperada, interpretada aqui como fruto de influência dos particípios rizotônicos com -nt-. Assinale-se, porém, que os demais casos de influência têm como vogal tônica $i$ enquanto a forma em questão tem $a$.
} 
rizotônicas (36 com apenas forma rizotônica e 28 com forma rizotônica e forma arrizotônica). Desses 64 itens, em 33 casos o particípio passado rizotônico espanhol deriva claramente do particípio passado rizotônico latino correspondente (p. ex., lat. attentum e esp. atento). Os demais 31 podem ser distribuídos em 6 grupos.

O primeiro grupo ( 8 itens), todos com correspondência latina, se refere aos relacionados ao particípio passado arrizotônico latino da $3^{\mathrm{a}}$ conjugação de tema em $\bar{u}$ : lat. solūtum e esp. suelto ${ }^{12}$; lat. absolūtum e esp. absuelto; lat. resolūtum e esp. resuelto; lat. volütum e esp. vuelto; lat. devolütum e esp. devuelto; lat. involutum e esp. envuelto; lat. revolūtum e esp. revuelto. Segundo Lloyd (1993, p. 500-501), a influência de alguns verbos sobre outros conduziu à criação analógica de novos particípios no latim tardio: "os particípios arrizotônicos VOLŪTUS (VOLVERE 'dar volta') e SOLŪTUS (< SOLVERE 'soltar, liberar') também foram substituídos por outros com acento no radical que deram vuelto e suelto" (tradução minha).

O segundo grupo (3 itens), todos com correspondência latina, se refere aos relacionados à generalização dos morfemas de particípios -to: lat. visum e esp. visto; lat. provisum e esp. provisto; e lat. provisum e esp. previsto. Segundo Lloyd (1993, p. 500-501), a influência de alguns verbos sobre outros também seria a causa dessas substituições: "o lat. cl. vīsus (VIDĒRE 'ver') deve ter sido substituído por *VĪsTUS > visto" (tradução minha).

O terceiro grupo (3 itens), com correspondência latina, refere-se aos relacionados originariamente a adjetivos no latim: lat. extensum (adj.) e esp. extenso (part. pas.); lat. manifestus (adj.) e esp. manifiesto (part. pas.); lat. salvus (adj.) e esp. salvo (part. pas.).

O quarto grupo (6 itens), sem correspondência latina, refere-se a casos de supletivismo: lat. confitèri/confessus sum, mas esp. confesar (infinitivo diferente do latino)/confesso (particípio igual ao latino); lat. mŏri/mortus sum e esp. morire/morto; lat. eximěrelexemptum e esp. exentar/exento; lat. farcīre/fartum e esp. hartar/harto; lat. iungĕrel iunctum e esp. juntar/junto; e lat. sĕpĕlìre/sepultum e esp. sepultar/ sepulto. É de se notar que, neste grupo, as formas infinitivas derivadas inovadoras geralmente têm como base o infinitivo que está associado ao particípio que adota.

\footnotetext{
${ }^{12} \mathrm{O}$ particípio espanhol suelto vincula-se a dois verbos nessa língua (solver e soltar), sendo computado como referente a 2 itens.
} 
O quinto grupo (10 itens), sem correspondência latina, são derivados prefixais de formas com correspondência latina: esp. contrahecho, deshecho e rehecho (cf. lat. factum e esp. hecho); esp. reabierto e entreabierto (cf. lat. apertum e esp. abierto); esp. encubierto (cf. lat. coopertum e esp. cubierto); e esp. disdicho (cf. lat. dictum e esp. dicho); esp. bienquisto e malquisto (cf. lat. qucesitum), esp. desenvuelto (cf. lat. involütum e esp. envuelto).

O sexto grupo (1 item), sem correspondência latina, é um caso mais complexo: o esp. despertar/despierto derivaria de uma suposta base (*espertar/*espierto) que não se verifica no espanhol, logo seria um caso de derivação prefixal no próprio latim, da forma hipotética latina dis + experğ̌scěre/expergĭtum, com consequente perda da base.

Em síntese, embora aproximadamente metade dos particípios rizotônicos espanhóis seja efetivamente herança de particípios latinos correspondentes $(33 / 64=51,6 \%)$, os demais $(31 / 64=48,4 \%)$ não o são. Entretanto, grande parte desses 31 itens no espanhol apresenta particípio passado rizotônico originado de particípio passado rizotônico latino diferente, tendo sido modificado por processos analógicos (como generalização de -to e -so, derivação prefixal, etc.) ou adotado por supletivismo (de adjetivos e de particípios de outros verbos latinos): apenas 8 itens (de $3^{\mathrm{a}}$ conjugação de tema em $\bar{u}$ ) eram originariamente arrizotônicos. Pode-se dizer, portanto, que, no espanhol, quase todas as formas rizotônicas têm origem latina, sejam as herdadas das correspondentes latinas (as que passaram apenas por mudanças fonéticas) sejam as não herdadas das correspondentes latinas (as que passaram por processo analógico ou foram tomadas de outros paradigmas ou classes).

As principais diferenças entre o italiano e o espanhol estão no fato de aquele ter generalização dos morfemas de particípios -so mas este não, e ainda no fato de aquele ter mudança analógica que determinou uma evolução fônica não prevista (-kt- > -nt-) mas este não.

Dos 247 itens do corpus, 237 têm dados referentes ao português (categorias I-E-P, I-P, E-P e P). Dentre esses 237, 210 apresentam uma ou mais formas rizotônicas (23 com apenas forma rizotônica e $187 \mathrm{com}$ forma rizotônica e forma arrizotônica ${ }^{13}$ ). Desses 210 itens, em 111 casos o

${ }^{13}$ Em 7 casos, há 3 formas de particípio passado: (a) com correspondência latina: lat. captivāre/captivatum e port. cativar/cativado-cativo-capto; lat. absolvěre/absolutum e port. absolver/absolvido-absoluto-absolto; lat coquĕre-cŏcĕre/coctum e port. cozer/ 
particípio passado rizotônico do português deriva claramente do particípio passado rizotônico latino (p. ex., lat. possessum e port. possesso). Os demais 109 itens podem ser distribuídos em 8 grupos.

O primeiro grupo (6 itens), alguns com correspondência latina, se refere aos relacionados ao particípio passado arrizotônico latino da $3^{\text {a }}$ conjugação de tema em $\bar{u}$ : lat. solūtum e port. solto; lat. absolūtum e port. absolto; lat. volūtum e port. volto ${ }^{14}$; lat. involutum e port. envolto; e lat. revolütum e port. revolto. Diferentemente do italiano e do espanhol, o português manteve uma forma arrizotônica em alguns casos desse grupo (ao lado de outra arrizotônica): cf. lat. solūtum e port. solultosolvido; lat. resolūtum e port. resoluto-resolvido; lat. devolūtum e port. devoluto-devolvido; lat. dilütum e port. diluto-diluído; e lat. instructum e port. instruto-instruído.

O segundo grupo (5 itens), com correspondência latina, se refere aos relacionados à generalização dos morfemas de particípios -to e -so nas formas com correspondência no latim: lat. visum e port. visto; lat. proevisum e port. previsto; lat. surrectum e port. surto; lat. abscōnditum e port. esconso; e lat. subtentum e it. subtenso.

O terceiro grupo (30 itens), também com correspondência latina, se refere aos relacionados originariamente a adjetivos no latim: p. ex., lat. coecus (adj.) e port. cego (part. pas.).

O quarto grupo (32 itens), sem correspondência latina, refere-se a casos de supletivismo: p. ex., lat. confitēri/confessus sum, mas port. confessar (infinitivo diferente do latino)/confesso (particípio igual ao latino). É de se notar que, neste grupo, as formas infinitivas derivadas inovadoras geralmente têm como base o infinitivo que está associado ao particípio que adota.

O quinto grupo (15 itens), sem correspondência latina, são derivados prefixais de formas com correspondência latina: port. contrafeito, desfeito e refeito (cf. lat.factum e port. feito); port. desaberto, reaberto e entreaberto (cf. lat. apertum e port. aberto); port. encoberto (cf. lat. coopertum e port.

cozido-cozeito-coito; lat. acceptāre/acceptatum e port. aceitar/aceitado-aceito-aceite; lat. abscōndĕrelabscōnditum e port. esconder/escondido-escuso-esconso; (b) sem correspondência latina: port. extremar/extremado-extremo-extreme; port. assentar/ assentado-assento-assente.

${ }^{14} \mathrm{O}$ particípio português volto vincula-se a dois verbos nessa língua (volver e voltar), sendo computado como referente a 2 itens. 
coberto); e port. desdito (cf. lat. dictum e port. dito); port. benquisto ${ }^{15}$ e malquisto ${ }^{16}$ (cf. lat. quoesitum e port. quisto); port. desenvolto (cf. lat. involütum e port. envolto); port. surpreso (cf. lat. prensum e port. preso); e port. desperto (cf. lat. expergĭtum e port. esperto).

O sexto grupo (2 itens), com correspondência latina, apresenta substituição de uma forma rizotônica latina por arrizotônica românica (mudança analógica), cuja evolução fonética a fez novamente rizotônica: lat. ventum e port. vindo $(<$ vĩido $<$ vẽido $<*$ uenītum $)$; e lat. conventum e port. convindo.

O sétimo grupo (17 itens), alguns com correspondência latina e alguns sem correspondência, refere-se às criações analógicas que certamente tomaram por modelo os casos de particípio duplos já existentes na língua: p. ex., port. assentar/assentado-assento-assente. Um traço distintivo do português está justamente nesse grupo: as criações analógicas de tema nominal em e. Williams (1991, p. 190) chama os itens dessa classe de particípios truncados.

O oitavo grupo ( 2 itens) é formado por casos muito idiossincráticos: lat. coquĕre-cŏcĕre/coctum e port. cozer/cozido-coito-cozeito e lat. excurrěre/excursum e port. escorrer/escorrido-escorreito. $\mathrm{O}$ aspecto idiossincrático está nas formações com -eito. Pereira (1945, p. 159) associa a forma escorreito ao infinitivo escorrer, mas Houaiss (2001) apresenta como etimologia "lat. *excorrectus 'sem erro, sem defeito, correto', ligado ao v. do lat. tar. excorrigěre, der. de corrigěre”, ou seja, com afinidade com o verbo corrigir. É possível que ambas as formações com -eito possam ter sido influenciadas por particípios terminados em -eito, como feito e derivados, aceito, eleito, colheito, sujeito, etc.

Em síntese, embora aproximadamente metade dos particípios rizotônicos portugueses seja efetivamente herança de particípios latinos correspondentes $(111 / 210=52,9 \%)$, os demais $(109 / 210=47,1 \%)$ não o são. Entretanto, grande parte desses 109 itens no português apresenta particípio passado rizotônico originado de particípio passado rizotônico latino, tendo sido modificado por processos analógicos (como generalização de -to e -so, derivação prefixal, etc.) ou adotado por supletivismo (de adjetivos e de particípios de outros verbos latinos). Apenas 6 itens (de $3^{\text {a }}$ conjugação de tema em $\bar{u}$ ) eram originariamente

\footnotetext{
15 Particípio rizotônico no português de 2 verbos: benquerer e benquistar.

${ }^{16}$ Particípio rizotônico no português de 2 verbos: malquerer e malquistar.
} 
arrizotônicos e 17 itens são criações analógicas independentes de derivação. Pode-se dizer, portanto, que, no português, quase todas as formas rizotônicas têm origem latina, sejam as herdadas das correspondentes latinas (as que passaram apenas por mudanças fonéticas) sejam as não herdadas das correspondentes latinas (as que passaram por processo analógico ou foram tomadas de outros paradigmas ou classes). Diferentemente do italiano e do espanhol, o português apresenta dois processos ausentes nos demais: (a) formação de particípio rizotônico por criação analógica, que Williams (1991) chamou de truncada, sobretudo na $1^{\text {a }}$ conjugação (cf. port. faltar/faltado e falto) e (b) formação de particípio rizotônico de tema nominal em e por criação analógica.

Agora é possível responder à pergunta colocada: seriam todos os particípios passados rizotônicos românicos heranças latinas, e não formações românicas? A resposta é não. Embora a maioria dos particípios passados rizotônicos românicos seja efetivamente herança dos particípios passados rizotônicos latinos com as respectivas mudanças fônicas $(104 / 149$ no italiano $=69,8 \% ; 33 / 64$ no espanhol $=51,6 \% ; 111 / 210$ no português $=52,9 \%$ ), o quadro envolve grande diversidade de fontes de formas rizotônicas, como demonstrado acima.

Uma última questão é avaliar a relação entre os particípios passados rizotônicos românicos herdados do latim e o paradigma de conjugação, a fim de que se possa avaliar a segunda hipótese de trabalho do presente estudo, segundo a qual os particípios passados rizotônicos românicos da $1^{\mathrm{a}}$ conjugação seriam predominantemente inovações românicas, uma vez que formas rizotônicas nessa conjugação eram raras no latim. 
Tabela 5 - Particípios passados rizotônicos românicos por paradigma de conjugação:herdados e não-herdados ${ }^{17}$

\begin{tabular}{|c|c|c|c|c|c|c|}
\hline \multirow[b]{2}{*}{ Conjugação } & \multicolumn{2}{|c|}{ Italiano } & \multicolumn{2}{|c|}{ Espanhol } & \multicolumn{2}{|c|}{ Português } \\
\hline & Herdados & $\begin{array}{c}\text { Não } \\
\text { Herdados }\end{array}$ & Herdados & $\begin{array}{c}\text { Não } \\
\text { Herdados }\end{array}$ & Herdados & Não Herdados \\
\hline $\begin{array}{c}1^{\mathrm{a}} \\
\text { conjugação }\end{array}$ & $\begin{array}{c}2 / 6 \\
(33,3 \%)\end{array}$ & $4 / 6(66,6 \%)$ & - & $\begin{array}{c}8 / 8 \\
(100 \%)\end{array}$ & $1 / 77(1,3 \%)$ & $76 / 77(98,7 \%)$ \\
\hline $\begin{array}{c}2^{\mathrm{a}} \\
\text { conjugação } \\
\text { (infinitivo } \\
\text { arrizotônico) }\end{array}$ & - & $4 / 4(100 \%)$ & $\begin{array}{c}15 / 33 \\
(45,5 \%)\end{array}$ & $\begin{array}{c}18 / 33 \\
(54,5 \%)\end{array}$ & $\begin{array}{c}51 / 66 \\
(77,3 \%)\end{array}$ & $15 / 66(22,7 \%)$ \\
\hline $\begin{array}{c}2^{\mathrm{a}} \\
\text { conjugação } \\
\text { (infinitivo } \\
\text { rizotônico) }\end{array}$ & $\begin{array}{c}91 / 122 \\
(74,6 \%)\end{array}$ & $\begin{array}{c}31 / 122 \\
(35,2 \%)\end{array}$ & - & - & - & - \\
\hline $\begin{array}{c}3^{\mathrm{a}} \\
\text { conjugação }\end{array}$ & $\begin{array}{c}11 / 17 \\
(64,7 \%)\end{array}$ & $6 / 17(35,3 \%)$ & $\begin{array}{c}18 / 23 \\
(78,3 \%)\end{array}$ & $\begin{array}{c}5 / 23 \\
(21,7 \%)\end{array}$ & $\begin{array}{c}59 / 67 \\
(88,1 \%)\end{array}$ & 8/67 (11,9\%) \\
\hline Total & $\begin{array}{l}104 / 149 \\
(69,8 \%)\end{array}$ & $\begin{array}{c}45 / 147 \\
(27,2 \%)\end{array}$ & $\begin{array}{c}33 / 64 \\
(51,6 \%)\end{array}$ & $\begin{array}{c}31 / 64 \\
(48,4 \%)\end{array}$ & $\begin{array}{c}111 / 210 \\
(52,9 \%)\end{array}$ & $\begin{array}{l}109 / 210 \\
(47,1 \%)\end{array}$ \\
\hline
\end{tabular}

Os dados da Tabela 5 confirmam a segunda hipótese, uma vez que os particípios passados rizotônicos herdados de $1^{\text {a }}$ conjugação no italiano $(33,3 \%)$, no espanhol $(0 \%)$ e no português $(1,3 \%)$ são menos numerosos do que os não herdados (respectivamente, 66,6\%, 100\% e $98,7 \%$ ). Como os particípios passados rizotônicos de $1^{\text {a }}$ conjugação eram raros no latim, consequentemente os diversos que existem nas línguas românicas são essencialmente inovações.

\section{Conclusão}

Na seção anterior, foi feita uma análise detalhada da questão dos particípios passados rizotônicos no italiano, no espanhol e no português. Nesta seção, apresenta-se uma síntese do que foi apurado.

${ }^{17}$ Consideram-se aqui como herdados apenas os particípios passados rizotônicos românicos que constituem continuação histórica de particípios passados rizotônicos latinos correspondentes com suas respectivas mudanças fônicas, sem nenhum tipo de interferência analógica ou adoção por supletivismo. 
Convém começar esta seção tratando das duas hipóteses de trabalho que serviram de ponto de partida para esta análise.

Segundo a primeira hipótese, os particípios passados rizotônicos no italiano estariam predominantemente na $2^{\mathrm{a}}$ conjugação, diferentemente do espanhol e do português, pois aquela língua manteve infinitivos rizotônicos nessa conjugação: os dados da Tabela 2 confirmaram essa hipótese.

De acordo com a segunda hipótese, os particípios passados rizotônicos românicos da $1^{\mathrm{a}}$ conjugação seriam predominantemente criações analógicas que constituem inovações românicas, uma vez que formas rizotônicas nessa conjugação eram raras no latim: os dados da Tabela 5 confirmaram essa hipótese para o italiano, o espanhol e o português.

Indo além das hipóteses, o presente estudo permitiu verificar ainda os seguintes fatos mais gerais sobre os particípios passados rizotônicos românicos.

A fonte dos particípios passados rizotônicos românicos é bastante diversificada, embora seja relevante a herança de particípios rizotônicos latinos correspondentes: cf. lat. transcriptum, it. trascritto e esp./port. transcrito.

Outro tipo de fonte são os adjetivos latinos que foram incorporados ao paradigma de conjugação verbal como particípios passados rizotônicos: trata-se de processo ocorrido no italiano, no espanhol e no português, raramente nos dois primeiros e menos raramente no último: cf. lat. extentum (particípio passado)/extensum (adjetivo), it. esteso e esp./port. extenso.

O supletivismo (adoção de particípio de um dado paradigma em outro) também é uma das fontes dos particípios passados rizotônicos românicos: cf. lat. sepultāre/sepultatum e sěpělìre/sepultum mas esp./ port. sepultare/sepultado-sepulto.

Diferentes tipos de mudança analógica atuaram sobre o sistema verbal latino e/ou românico dando origem a parte dos atuais particípios passados rizotônicos românicos:

(a) Reestruturação dos particípios passados arrizotônicos latinos da $3^{\text {a }}$ conjugação de tema em $\bar{u}$ como rizotônicos da $3^{\text {a }}$ conjugação de tema em consoante, com repercussão no italiano, no espanhol e no português (cf. lat. revolütum, it. rivolto, esp. revuelto e port. revolto): esse processo propiciou uma simplificação do paradigma da $3^{\mathrm{a}}$ conjugação.

(b) Reestruturação na evolução fônica dos particípios passados rizotônicos latinos com grupo consonantal interno - $k t$ - (com resultado esperado -tt-) tendo como modelo os com o grupo -nkt- (com resultado esperado -nt-), fato restrito ao italiano: cf. lat. frictum e it. fritto; lat. tinctum e o it. tinto; lat. depictum e it. dipinto. 
(c) Generalização dos morfemas de particípio passado -to e -so (já existentes no latim como -tus e -sus). A generalização do morfema -to aparece no italiano, no espanhol e no português (cf. lat. visum e it./ esp./port. visto), enquanto a de -so ocorre apenas no italiano (cf. lat. perditum e it. perso). A generalização de -to é bastante rara no espanhol e no português, mas mais comum no italiano.

Há também diferentes tipos de criação analógica que atuaram sobre o sistema verbal latino e/ou românico dando origem a outra parte dos atuais particípios passados rizotônicos românicos:

(a) Formação de derivados de verbos que já apresentam particípio passado rizotônico: cf. it. contraffatto, esp. contrahecho e port. contrafeito (lat. factum, it. fatto, esp. hecho e port. feito).

(b) Formação de particípios por analogia com par particípio passado arrizotônico-rizotônico (de tema em $o$ ) apenas no português: cf. lat. pacatum e port. pagado/pago.

(c) Formação de particípios por analogia com par particípio passado-adjetivo (de tema em $e$ ) apenas no português: cf. lat. liberatum (particípio passado)/liber (adjetivo) e port. livrado (particípio passado arrizotônico)/livre (particípio passado rizotônico/adjetivo) frente ao lat. integratum e ao port. entregado (particípio passado arrizotônico)/entregue (particípio passado rizotônico analógico).

\section{Referências}

AINCIBURU, M. C. et al. Vía rápida: curso intensivo de español. Barcelona: Difusión, 2011.

BAILINI, S.; CONSONNO, S. I verbi italiani. Firenze: Alma Edizioni, 2004.

BALLESTEROS, P. D.; SORDO, M. L. R. Las formas verbales. Madrid: Edinumen, 2005.

BECHARA, E. Moderna gramática portuguesa. 37. ed. rev., ampl., atual. conforme o novo Acordo Ortográfico. Rio de Janeiro: Nova Fronteira, 2009.

BIRELLO, M.; VILAGRASA, A. Bravissimo!: corso d'italiano. Barcellona: Difusión; Firenze: Bulgarini, 2012. v. 1.

BYNON, T. Historical Linguistics. Cambridge: Cambridge University Press, 1993. 
CHIUCHIÙ, A.; CHIUCHIÙ, G. Grammatica e comunicazione: tavole sinottiche dell'italiano LS e L2. Perugia: Guerra Edizioni, 2012.

CHIUCHIÙ, A.; FAZI, M. C.; BAGIANTI, M. R. I verbi italiani: regolari e irregolari. 2. ed. Perugia: Guerra Edizioni, 2007.

CONFORTI, C.; CUSIMANO, L. Nuovo linea diretta. Perugia: Guerra Edizioni, 2005. v. 1a.

CUNHA, A. G. da. Dicionário etimológico da língua portuguesa. 4. ed. Rio de Janeiro: Lexikon Editora Digital, 2010.

CUNHA, C.; CINTRA, L. Nova gramática do português contemporâneo. 4. ed. Rio de Janeiro: Lexikon Editora Digital, 2007.

DIACO, M.; KRAFT, L. A arte de conjugar verbos: verbos italianos. Tradução de Mônica Stahel. São Paulo: Martins Fontes, 2003.

ERNOUT, A. Morphologie historique du latin. 3. éd. rev. corr. Paris: C. Klincksieck, 1953.

FARIA, E. Gramática superior da língua latina. Rio de Janeiro: Acadêmica, 1958. (Biblioteca Brasileira de Filologia, 14)

GRANDGENT, C. H. From Latin to Italian: An Historical Outline of the Phonology and Morphology of the Italian Language. Cambridge, MA: Harvard University Press, 1933.

GRANDGENT, C. H. Introducción al latín vulgar. 2. ed. Madrid: CSICRevista de Filologia Española, 1952.

HOUAISS, A. Dicionário Houaiss da língua portuguesa. Rio de Janeiro: Objetiva, 2001. 1 CD-ROM.

LLOYD, P. M. Del latín al español. Madrid: Gredos, 1993.

LOBATO, L. Sobre a forma do particípio do português e o estatuto dos traços formais. São Paulo: DELTA, 1999. Disponível em: $<$ http://www.scielo.br/scielo.php?script=sci_arttext\&pid=S0102$44501999000100005 \& \operatorname{lng}=$ en\&nrm=iso $>$. Acesso em: 8 jul. 2015.

MARIN, T.; MAGNELLI, S. Nuovo progetto italiano. Milano: Edizioni Edilingua, 2010. v. 1. 
MARTINS, M. D.; PACHECO, M. C. G. Temas de gramática contemporánea de la lengua española. São Paulo: Companhia Editora Nacional, 2005.

MORENO, C. et al. En gramática. Madrid: Anaya, 2007.

NOCCHI, Susanna. Grammatica pratica della lingua italiana. Firenze: Alma Edizioni, 2011.

PECCIANTI, M. C. Parola per parola. Firenze: Giunti Editoriale, 1993. V. 1.

PEREIRA, E. C. Gramática expositiva: curso superior. 65. ed. São Paulo: Companhia Editora Nacional, 1945.

PERINI, M. A. Gramática do português brasileiro. São Paulo: Parábola Editorial, 2010.

RAYA, R. A. et al. Gramática básica del estudiante de español. Barcelona: Difusión, 2005.

REAL ACADEMIA ESPAÑOLA. Gramática de la lengua española. Madrid: Librería y Casa Editorial Hernano, 1928.

REIS, O. Breviário da conjugação de verbos. 38 . ed. rev. atual. Rio de Janeiro: Francisco Alves, 1978.

TORREGO, L. G. Gramática didáctica del español. 10. ed. Madrid: Ediciones SM, 2011.

TRIFONE, P.; PALERMO, M. Grammatica italiana di base. Bologna: Zanichelli Editore, 2014.

WILLIAMS, E. B. Do latim ao português: fonologia e morfologia históricas da língua portuguêsa. 5. ed. Rio de Janeiro: Tempo Brasileiro, 1991.

Recebido em: 10 de abril de 2018. Aprovado em: 30 de maio de 2018. 